\title{
Microwave Assisted Liquid Phase Synthesis of Benzimidazolo Benzothiophenes for Antimicrobial Activity
}

\author{
DEEPTHI KINI, HARISH KUMAR and MANJUNATH GHATE* \\ Department of Pharmaceutical Chemistry, \\ Krupanidhi College of Pharmacy, Bangalore, Karnataka-560035, India. \\ ghate72@gmail.com
}

Received 30 April 2009; Accepted 25 June 2009

\begin{abstract}
Benzimidazolo benzothiophene derivatives were prepared by liquid phase combinatorial synthesis using soluble polymer support PEG 5000 and 4-fluoro-3-nitrobenzoic acid as starting materials with substituted primary amines. All these synthesized compounds were established by the spectral data and tested for antimicrobial activity against gram positive bacteria, i.e. S. aureus, B. subtilis and gram negative bacteria, E.coli and P.aeruginosa and anti fungal activity against $C$. albicans. Ampicillin and ciprofloxacin were used as standard for antibacterial activity and cotrimoxazole for anti fungal activity. Compared with standards compounds (1a-h) showed significant activity against bacterial species and $\mathbf{1 g}$ showed significant activity against fungal species.
\end{abstract}

Keywords: Combinatorial synthesis, Antimicrobial study, Benzimidazolo derivatives.

\section{Introduction}

Combinatorial chemistry has emerged as a powerful tool for synthesizing large number of medicinally active substances ${ }^{1-3}$. Most of the combinatorial libraries were synthesized in a solid support and one of the interesting approach is liquid phase synthesis approach, by which molecules were synthesized on a soluble polymer. In comparison to the solid support like resins in this approach a soluble polymer (Poly ethylene glycol) is used as a support. The polymer is soluble in most of the organic solvents and has tendency to precipitate in particular solvent ${ }^{4,5}$. The unique property of precipitation makes this method to solve most of the drawbacks of solid phase synthesis like separation, purification as well as monitoring the reaction. Liquid phase synthetic approach has many advantages like simple reaction conditions, easy monitoring by TLC and simple purification, for instance, after completion of the reaction the product can be separated easily by precipitation and filtration. After completion of the reaction the polymer bound 
compound was dissolved in organic solvent and easily precipitated by using particular solvent like diethyl ether. The PEG bound compound gets precipitated whereas the impurities are left behind. The other problem of solid phase or the traditional method synthesis like slow reaction and use of drastic condition for the reaction can be avoided by this methods ${ }^{6-10}$.

Benzimidazole scaffold is constituent of many of drugs and medicinally active heterocyclic compounds that exhibit wide range of biological activities ${ }^{11}$. It is present in many compounds like Vit $\mathrm{B}_{12}$, albendazole, mebendazole and thiabendazole which are used as antihelmintic drugs ${ }^{12,13}$. The 2 -substituted benzimidazoles and their derivatives have been found to possess various biological activities including as inhibitors of MDAMB-231 human breast cancer cell proliferation ${ }^{14}$, TRPV1 antagonists ${ }^{15}$, selective antagonists of the human melanocortin-4 receptor $^{16}$, kinase inhibitors ${ }^{17}$, antimicrobial activity $^{18}$ and $\mathrm{MCH}-1 \mathrm{R}$ antagonists ${ }^{19}$. Benzothiophene analogues represent major class of medicinally important compound and possess wide variety of activities including vascular $5-\mathrm{HT}_{1 \mathrm{~B}}$ receptor $^{20}$, selective inhibitors of IKK- $\varepsilon$ kinase $^{21}$, partial agonist activity at the benzodiazepine receptor ${ }^{22}$, ligands for $\alpha_{1}$-and $5 \mathrm{HT}_{1 \mathrm{~A}}$-receptors ${ }^{23}$. The importance of benzimidazoles and benzothiophenes in the biological systems encouraged us to design and synthesize compounds containing both benzimidazole and benzothiophene ring systems. In continuation of our work on bioactive heterocyclic systems, we now wish to report our results towards the synthesis of benzimidazolo benzothiophenes in a liquid phase synthetic approach.

\section{Experimental}

The melting points were determined in Thiel's open capillaries and were uncorrected. IR absorption spectra were recorded on spectrophotometer using $\mathrm{KBr}$ pellets and ${ }^{1} \mathrm{H}-\mathrm{NMR}$ spectra were recorded in acetone-d6 and $\mathrm{CDCl}_{3}$ on bruker DRX-400 instrument (chemical shift in $\delta \mathrm{ppm}$ ). The purity of the compounds was routinely checked by TLC using silica gel-G ethyl acetate as an eluent. The compounds (2-5) were prepared according to the literature methods ${ }^{24}$.

\section{Synthesis of polymer bound compound (6)}

The polymer bound diamino compound $\mathbf{5}$ was dissolved in dichloromethane, treated with 1.2 mol of 4-mercaptobenzoic acid (MBA), $1.2 \mathrm{~mol}$ of DCC and a pinch of DMAP. The reaction mixture was kept in the microwave cavity for $20 \mathrm{~min}$. We have tried the reaction in conventional method which took $24 \mathrm{~h}$ for the completion of the reaction whereas under microwave reaction was completed within $20 \mathrm{~min}$. The completion of the reaction was checked by TLC and NMR. After the completion of the reaction, the solution was filtered to remove the excess of DCC and DMAP salts. The purification was done by cooling the filtrate to $0{ }^{\circ} \mathrm{C}$ and addition of cold diethyl ether to precipitate to afford PEG bound compound (6).

\section{Synthesis of polymer bound compound(7)}

PEG bound 3-amino-4-mercapto benzene (6) was treated with trifluoro acetic acid and ethylene dichloride in the ratio of 1:10 and refluxed for about $12 \mathrm{~h}$. The same reaction was carried under microwave irradiation has taken only 20 minutes for the completion of the reaction. After the completion of the reaction the cold diethyl ether was added to the reaction mixture to precipitate the PEG bound 2-substituted benzimidazole (7). 


\section{Synthesis of polymer bound compound $(\mathbf{8})$}

The solution of PEG bound mercaptobenzimidazole was treated with chloroacetone (1.2 $\mathrm{mol})$, triethylamine $(1.2 \mathrm{~mol})$ in dichloromethane and stirred for $12 \mathrm{~h}$ at room temperature. The same reaction was also carried under microwave irradiation for about $10 \mathrm{~min}$. After completion of the reaction the reaction mixture was directly treated with cold diethyl ether to precipitate the product. The impurities were removed by washing with cold diethyl ether repeatly.

\section{Cleavage of polyethylene glycol compound (9)}

The PEG bound compound (8) was dissolved in methanol and treated with $0.5 \mathrm{~g}$ of sodium methoxide and stirred for $10 \mathrm{~h}$ at room temperature. After the completion of the reaction the separated PEG and the compound were treated with cold diethyl ether. Only the PEG precipitated whereas the compound dissolved in diethyl ether. The filtrate was concentrated under reduced pressure to give the compound (9).

Synthesis of 1-substituted-2-(3-methyl-benzo[b]thiophen-6-yl)-3H-benzoimidazole5-carboxylic acid methyl ester (1)

1-Substituted-2-(4-aceto-methyl-thio-phenyl)-1 $H$-benzoimidazole-5-carboxylic acid methyl ester $(1.0 \mathrm{~mol})$ was treated with poly phosphoric acid (PPA) and heated on a water bath for $4 \mathrm{~h}$. After the completion of the reaction the reaction mixture was concentrated and added to crush ice. The solid separated was filtered and dried. The compound was purified by column chromatography.

\section{Antibacterial assay}

The cultures were obtained in Mueller-Hinton broth for all the bacteria after $24 \mathrm{~h}$ of incubation at $37{ }^{\circ} \mathrm{C}$. Testing was carried out on Mueller-Hinton broth at $\mathrm{pH} 7.4$ and the two fold serial dilution technique was applied. A set of tubes containing only inoculated broth was kept as control. After incubation for $24 \mathrm{~h}$ at $37{ }^{\circ} \mathrm{C}$, the last tube with no growth of microorganism was recorded to represent MIC. Every experiment in the antibacterial assay was replicated twice in order to define the MIC values.

\section{Antifungal assay}

The Saccharomyces cerevisiae and Candida albicans were maintained in RPMI 1640 broth. The test procedure was applied according to the NCCLS protocols. A set of tubes containing only inoculated broth was kept as control. After incubation for $48 \mathrm{~h}$ at $35^{\circ} \mathrm{C}$, the last tube with no fungal growth was recorded to represent minimum inhibitory concentration (MIC), expressed in $1 \mu \mathrm{g} / \mathrm{mL}$. Every experiment in the antifungal assay was replicated twice in order to define the MIC values.

\section{Results and Discussion}

To obtain targeted benzimidazolo benzothiophenes (1), first we coupled PEG (polyethylene glycol 5000, MeO-PEG-OH) with 3-nitro 4-flouro benzoic acid (2) using DCC, catalytic amount of DMAP as coupling agent in dichloro methane in open vessel under microwave irradiation (Scheme 1). The resulting polymer bound 3-nitro 4-fluro benzoic acid (3) was treated with ice-cooled diethyl ether and purified by precipitating the polymer followed by washing with excess amount ether to remove the unreacted reagents and dried under reduced pressure. The purity of the polymer bound acid was checked by TLC and NMR and the ratio of the polymer bound the acid is calculated from NMR data. 
In the next step, the nucleophilic displacement of fluoro group with variety of amines under microwave cavity for $20 \mathrm{~min}$ furnished the PEG bound $o$-nitroaniline (4). The purification was done in similar way. The compound 4 was reduced with zinc and ammonium chloride in methanol to afford diamine compound 5. This reaction under microwave cavity has taken only 10 minutes for completion. The purification of the reaction mixture is done by filtration with elute to remove the zinc and the excess of methanol is removed under reduced pressure. Further the reaction mixture was purified by precipitating with cold diethyl ether.

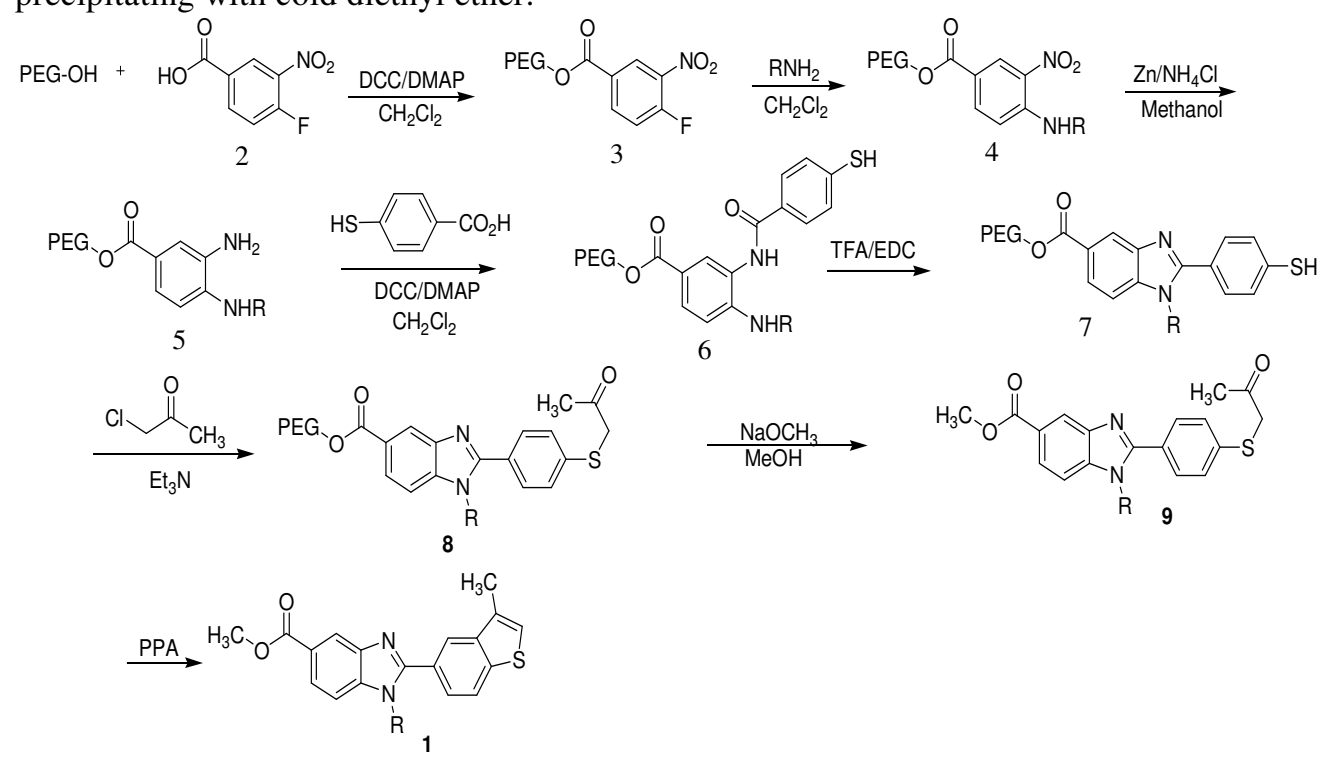

\section{Scheme 1}

Next, the PEG bound diamine compound 5 was treated with 4-mercapto benzoic acid to afford the compound $\mathbf{6}$, which was converted into compound 7 by treatment with chloroacetone. The last step of cyclisation was carried by treating the compound $\mathbf{7}$ with polyphosphoric acid however the compound starts charred by the process. We have used other reagent like sulphuric acid at different concentrations to carry out the reaction. The reaction did not undergo smoothly by such process. We have carried out the cylisation after the cleavage of the polymer from the compound. The polyemer bound compound 7 was first cleaved with sodium methoxide in methanol to afford the compound $\mathbf{8}$. The compound $\mathbf{8}$ was cyclised by using polyphosphoric acid under solvent free conditions in microwavae oven to afford the compound $\mathbf{1}$. All of the synthesized compounds were determined by physical data and spectral data (Table 1).

All the test compounds were assayed for antimicrobial activity against Staphylococcus aureus, Streptococcus faecalis, Bacillus subtilis (Gram-positive), and Escherichia coli, Klebsiella pneumoniae, Pseudomonas aeruginos (Gramnegative) bacteria and Saccharomyces cerevisiae and Candida albicans (fungi). The MIC was determined by using two-fold serial dilution method ${ }^{25,26}$ with $64-$ well microtest plates. Ampicillin, amoxycillin, tetracycline, streptomycin, clotrimazole were used as reference standards to compare the antibacterial and antifungal activities respectively. For determining both antibacterial and antifungal activities, the synthesized compounds and the control drugs were dissolved in 
redistilled dimethylsulphoxide (DMSO). Further dilutions were made at the required quantities of $320,160,80,40,20,10,5$ and $1 \mu \mathrm{g} / \mathrm{mL}$ respectively. In order to ensure that the solvent had no effect on bacterial growth, a control test was also performed containing broth supplemented with only DMSO at the same dilution used in our experiment. The MIC values were obtained from the lowest concentration of the test compound where the tubes remain clear, indicating that the bacterial growth was completely inhibited at this concentration. The results were given in Table 2 .

Table 1. Physical and spectral data of synthesized compounds (1a-h).

\begin{tabular}{|c|c|c|}
\hline Entry & $\mathrm{R}$ & Physical and Spectral data \\
\hline $1 \mathbf{a}$ & $\mathrm{CH}_{3}$ & $\begin{array}{l}\left.\text { Yield: } 77.3 \% ; \mathrm{R}_{\mathrm{f}}=0.57 \text { (ethyl acetate: } n \text {-hexane }=1: 4\right) ; \text { m.p. } 279-280 \\
{ }^{\circ} \mathrm{C} ; \mathrm{IR}\left(\mathrm{KBr} \mathrm{cm}{ }^{-1}\right): 3030(\mathrm{C}-\mathrm{H}-\mathrm{Ar}), 2854.5(\mathrm{CH}-\mathrm{Ali}), 1751(\mathrm{C}=\mathrm{O}), 1282.6 \\
\left(\mathrm{CH}_{2}-\mathrm{O}\right) ;{ }^{1} \mathrm{H} \mathrm{NMR}\left(300 \mathrm{MHz}, \mathrm{CDCl}_{3}\right): 2.43\left(3 \mathrm{H}, \mathrm{s}, \mathrm{CH}_{3}\right), 3.12(3 \mathrm{H}, \mathrm{S}, \\
\left.\mathrm{CH}_{3}\right), 3.90\left(3 \mathrm{H}, \mathrm{s}, \mathrm{OCH}_{3}\right), 7.38-8.75(7 \mathrm{H}, \mathrm{m}, \mathrm{Ar}-\mathrm{H}) .\end{array}$ \\
\hline $1 \mathbf{b}$ & $\mathrm{C}_{2} \mathrm{H}_{5}$ & $\begin{array}{l}\text { Yield: } 84.5 \% ; \mathrm{R}_{\mathrm{f}}=0.62(\text { ethyl acetate: } n \text {-hexane }=1: 4) ; \mathrm{m} . \mathrm{p} .245-247 \\
{ }^{\circ} \mathrm{C} ; \mathrm{IR}\left(\mathrm{KBr} \mathrm{cm}^{-1}\right): 3050(\mathrm{C}-\mathrm{H}-\mathrm{Ar}), 2874.5(\mathrm{CH}-\mathrm{Ali}), 1762(\mathrm{C}=\mathrm{O}), 1274 \\
\left(\mathrm{CH}_{2}-\mathrm{O}\right) ;{ }^{1} \mathrm{H} \mathrm{NMR}\left(300 \mathrm{MHz}, \mathrm{CDCl}_{3}\right): 1.55\left(3 \mathrm{H}, \mathrm{t}, \mathrm{CH}_{3}\right), 3.12(2 \mathrm{H}, \mathrm{q}, \\
\left.\mathrm{CH}_{2}\right), 3.90\left(3 \mathrm{H}, \mathrm{s}, \mathrm{OCH}_{3}\right), 7.40-8.70(7 \mathrm{H}, \mathrm{m}, \mathrm{Ar}-\mathrm{H}) .\end{array}$ \\
\hline 1c & & $\begin{array}{l}\text { Yield: } 81.6 \% ; \mathrm{R}_{\mathrm{f}}=0.55(\text { ethyl acetate: } n \text {-hexane }=1: 4) ; \text { m.p. } 183-185 \\
{ }^{\circ} \mathrm{C} ; \mathrm{IR}\left(\mathrm{KBr} \mathrm{cm}{ }^{-1}\right): 3120(\mathrm{C}-\mathrm{H}-\mathrm{Ar}), 2902.5(\mathrm{CH}-\mathrm{Ali}), 1758(\mathrm{C}=\mathrm{O}), 1222 \\
\left(\mathrm{CH}_{2}-\mathrm{O}\right) ;{ }^{1} \mathrm{H} \mathrm{NMR}\left(300 \mathrm{MHz}, \mathrm{CDCl}_{3}\right): 0.97\left(3 \mathrm{H}, \mathrm{t}, \mathrm{CH}_{3}\right), 1.82(2 \mathrm{H}, \mathrm{m}, \\
\left.\mathrm{CH}_{2}\right), 3.57\left(2 \mathrm{H}, \mathrm{t}, \mathrm{CH}_{2}\right), 3.92\left(3 \mathrm{H}, \mathrm{s}, \mathrm{OCH}_{3}\right), 7.54-8.67(7 \mathrm{H}, \mathrm{m}, \mathrm{Ar}-\mathrm{H}) .\end{array}$ \\
\hline 1d & & $\begin{array}{l}\left.\text { Yield: } 76.7 \% ; \mathrm{R}_{\mathrm{f}}=0.57 \text { (ethyl acetate: } n \text {-hexane }=1: 4\right) ; \text { m.p. } 294-295 \\
{ }^{\circ} \mathrm{C} ; \mathrm{IR}\left(\mathrm{KBr} \mathrm{cm}{ }^{-1}\right): 3102.0(\mathrm{C}-\mathrm{H}-\mathrm{Ar}), 2972.5(\mathrm{CH}-\mathrm{Ali}), 1761(\mathrm{C}=\mathrm{O}), 1252 \\
\left(\mathrm{CH}_{2}-\mathrm{O}\right) ;{ }^{1} \mathrm{H} \mathrm{NMR}\left(300 \mathrm{MHz}, \mathrm{CDCl}_{3}\right): 0.96\left(3 \mathrm{H}, \mathrm{s}, \mathrm{CH}_{3}\right), 1.32(2 \mathrm{H}, \mathrm{m}, \\
\left.\mathrm{CH}_{2}\right), 1.72\left(2 \mathrm{H}, \mathrm{m}, \mathrm{CH}_{2}\right), 3.45\left(2 \mathrm{H}, \mathrm{t}, \mathrm{CH}_{2}\right), 3.91\left(3 \mathrm{H}, \mathrm{S}, \mathrm{OCH}_{3}\right), 7.56- \\
8.68(7 \mathrm{H}, \mathrm{m}, \mathrm{Ar}-\mathrm{H}) .\end{array}$ \\
\hline $1 e$ & & $\begin{array}{l}\text { Yield: } 75.0 \% ; \mathrm{R}_{\mathrm{f}}=0.61(\text { ethyl acetate: } n \text {-hexane }=1: 4) ; \text { m.p. } 202-203 \\
{ }^{\circ} \mathrm{C} ; \mathrm{IR}\left(\mathrm{KBr} \mathrm{cm}^{-1}\right): 3114(\mathrm{C}-\mathrm{H}-\mathrm{Ar}), 2906(\mathrm{CH}-\mathrm{Ali}), 1756(\mathrm{C}=\mathrm{O}), 1282 \\
\left(\mathrm{CH}_{2}-\mathrm{O}\right) ;{ }^{1} \mathrm{H} \mathrm{NMR}\left(300 \mathrm{MHz}, \mathrm{CDCl}{ }_{3}\right): 2.43\left(3 \mathrm{H}, \mathrm{t}, \mathrm{CH}_{3}\right), 3.91(3 \mathrm{H}, \mathrm{S}, \\
\left.\mathrm{OCH}_{3}\right), 7.60-8.68(12 \mathrm{H}, \mathrm{m}, \mathrm{Ar}-\mathrm{H}) .\end{array}$ \\
\hline 1f & & $\begin{array}{l}\text { Yield: } 82.3 \% ; \mathrm{R}_{\mathrm{f}}=0.58(\text { ethyl acetate: } n \text {-hexane }=1: 4) ; \text { m.p. } 208-210 \\
{ }^{\circ} \mathrm{C} ; \mathrm{IR}\left(\mathrm{KBr} \mathrm{cm}^{-1}\right): 3105(\mathrm{C}-\mathrm{H}-\mathrm{Ar}), 2965(\mathrm{CH}-\mathrm{Ali}), 1744(\mathrm{C}=\mathrm{O}), 1274 \\
\left(\mathrm{CH}_{2}-\mathrm{O}\right) ;{ }^{1} \mathrm{H} \mathrm{NMR}\left(300 \mathrm{MHz}, \mathrm{CDCl}_{3}\right): 2.48\left(3 \mathrm{H}, \mathrm{s}, \mathrm{CH}_{3}\right), 1.12-1.22(10 \mathrm{H}, \\
\left.\mathrm{m}, \mathrm{CH}_{2}\right), 3.89\left(3 \mathrm{H}, \mathrm{s}, \mathrm{OCH}_{3}\right) 7.60-8.68(7 \mathrm{H}, \mathrm{m}, \mathrm{Ar}-\mathrm{H}) .\end{array}$ \\
\hline $1 g$ & & $\begin{array}{l}\text { Yield: } 83.3 \% ; \mathrm{R}_{\mathrm{f}}=0.62(\text { ethyl acetate: } n \text {-hexane }=1: 4) ; \text { m.p. } 193-194 \\
{ }^{\circ} \mathrm{C} ; \mathrm{IR}\left(\mathrm{KBr} \mathrm{cm}{ }^{-1}\right): 3115(\mathrm{C}-\mathrm{H}-\mathrm{Ar}), 2944(\mathrm{CH}-\mathrm{Ali}), 1746(\mathrm{C}=\mathrm{O}), 1287 \\
\left(\mathrm{CH}_{2}-\mathrm{O}\right) ;{ }^{1} \mathrm{H} \mathrm{NMR}\left(300 \mathrm{MHz}, \mathrm{CDCl}_{3}\right): 2.47\left(3 \mathrm{H}, \mathrm{s}, \mathrm{CH}_{3}\right), 3.85(3 \mathrm{H}, \mathrm{s}, \\
\left.\mathrm{OCH}_{3}\right), 7.56-8.80(14 \mathrm{H}, \mathrm{m}, \mathrm{Ar}-\mathrm{H}) .\end{array}$ \\
\hline $1 \mathrm{~h}$ & & $\begin{array}{l}\text { Yield: } 86.4 \% ; \mathrm{R}_{\mathrm{f}}=0.61(\text { ethyl acetate: } n \text {-hexane }=1: 4) ; \text { m.p. } 193-195 \\
{ }^{\circ} \mathrm{C} ; \mathrm{IR}\left(\mathrm{KBr} \mathrm{cm}{ }^{-1}\right): 3100(\mathrm{C}-\mathrm{H}-\mathrm{Ar}), 2962(\mathrm{CH}-\mathrm{Ali}), 1752(\mathrm{C}=\mathrm{O}), 1288 \\
\left(\mathrm{CH}_{2}-\mathrm{O}\right) ;{ }^{1} \mathrm{H} \mathrm{NMR}\left(300 \mathrm{MHz}, \mathrm{CDCl}_{3}\right): 1.07\left(3 \mathrm{H}, \mathrm{s}, \mathrm{CH}_{3}\right), 2.48(3 \mathrm{H}, \mathrm{s}, \\
\left.\mathrm{CH}_{3}\right), 3.90\left(3 \mathrm{H}, \mathrm{s}, \mathrm{OCH}_{3}\right), 7.33-8.60(11 \mathrm{H}, \mathrm{m}, \mathrm{Ar}-\mathrm{H}) .\end{array}$ \\
\hline
\end{tabular}


Table 2. Antimicrobial activity results (MIC, $\mu \mathrm{g} / \mathrm{mL}$ ) of the newly synthesized compounds with the standard drugs.

\begin{tabular}{|c|c|c|c|c|c|c|c|c|c|}
\hline \multirow[t]{2}{*}{ Entry } & \multirow[t]{2}{*}{$\mathrm{R}$} & \multicolumn{3}{|c|}{$\begin{array}{l}\text { Microorganisms } \\
\text { gram positive }\end{array}$} & \multicolumn{3}{|c|}{ Gram negative } & \multicolumn{2}{|c|}{ Fungus } \\
\hline & & S.A & S.F & B.S & E.C & K.P & P.A & C.A & S.C \\
\hline $1 \mathbf{a}$ & $\mathrm{CH}_{3}$ & 40 & 40 & 80 & 40 & 80 & 40 & 40 & 40 \\
\hline $1 b$ & $\mathrm{C}_{2} \mathrm{H}_{5}$ & 40 & 40 & 40 & 40 & 20 & 80 & 80 & 40 \\
\hline 1c & & 40 & 20 & 10 & 10 & 20 & 20 & 20 & 20 \\
\hline 1d & & 40 & 40 & 40 & 20 & 40 & 20 & 10 & 20 \\
\hline $1 e$ & & 20 & 20 & 20 & 20 & 20 & 10 & 10 & 10 \\
\hline 1f & & 10 & 20 & 20 & 20 & 20 & 20 & 10 & 10 \\
\hline $1 g$ & & 10 & 10 & 10 & 20 & 20 & 20 & 10 & 10 \\
\hline $1 \mathrm{~h}$ & & & & & & & & & \\
\hline & & 10 & 10 & 10 & 10 & 10 & 10 & 10 & 10 \\
\hline Ampicillin & & 5 & 5 & 5 & 20 & 40 & 320 & - & - \\
\hline Amoxycillin & & 5 & 5 & 5 & 5 & 20 & 320 & - & - \\
\hline Tetracycline & & 5 & 5 & 5 & 5 & 5 & 80 & - & - \\
\hline Stretomycin & & 5 & 80 & 40 & 5 & 5 & 160 & - & - \\
\hline Clotrimazole & & - & - & - & - & - & - & 5 & 5 \\
\hline
\end{tabular}

Abbreviations: S.A., Staphylococcus aureus (ATCC 6538); S.F., Streptococcus faecalis (ATCC 10541); B.S., Bacillus subtilis (ATCC 6033); E. C., Escherichia coli (ATCC 25922); K.P., Klebsiella pneumoniae (ATCC 52211); P.A., Pseudomonas aeruginosa (ATCC 27853); C.A., Candida albicans (ATCC 76615); S.C., Saccharomyces cerevisiae (ATCC 9763).

Among the synthesized compounds, benzonaptho and tolyl substituted compounds (1e, $\mathbf{1 g}, \mathbf{h h})$ were found to be more active compounds at an MIC value of $10-20 \mu \mathrm{g} / \mathrm{mL}$. Out of them the compound $\mathbf{1 h}$ is active against gram positive, gram negative and fungi at a concentration of $10 \mu \mathrm{g} / \mathrm{mL}$. Whereas $1 \mathrm{e}$ is active against gram negative and fungi while $\mathbf{1 g}$ is active against gram positive and fungi. Most of the derivatives except 1a exhibited significant antibacterial activity with MIC values of $20 \mu \mathrm{g} / \mathrm{mL}$ for the Gram negative Klebsiella pneumoniae which is effective in pneumoniae infections and often resistant to antibiotic therapy, providing higher potencies than the compared standard drugs. The antibacterial and antifungal activities of the different substituted compounds were shown in Table 2. As expected, the MICs of antibacterial (ampicillin) and antifungal (clotrimazole) control standards were lower than the synthesized compounds. The substitution of the benzo group attached at 1-position of the benzimidazole caused two-fold better potency against C.Abicans and Saccharomyces cerevisiae. However, holding methyl substitution to the benze group at 2-position shows increase in activity against all kinds of organisms tested. It is worth to note that the naptho substitution at benzimidazole showed better activity especially against the enteric Gram-positive Staphylococcus aureus (S.F., Streptococcus faecalis B.S., Bacillus subtilis. The alkyl substitution at 1-position of benzimidazole moiety exhibited less potency against most of the organisms. However, holding propyl substitution 
at the 1-position slightly increased the activity against E.coli and B. subtilis. The butyl substitution has shown significant avctivity against C.albicans. The substitution with cyclohexyl moiety at 1-position has shown significant acivity agaist S.aureus and fungi. These observations provide some predictions in order to design further antimicrobial active compounds prior to their synthesis following with molecular modeling studies.

\section{Conclusion}

In conclusion, we have synthesized a series of benzimidazolo benzothiophenes by microwave irradiation in a liquid phase synthesis format. This protocol presented many advantages, such as good to excellent yields, much shorter reaction time (5-12 min) and simple purification procedure. The drastic conditions of the classical synthetic approach can be made very simple by liquid phase approach. Bioassay of these compounds indicated that most of the compounds showed significant antimicrobial activity by twofold serial dilution technique method. Further bioassay, optimization and structure-activity relationship of the title compounds are underway.

\section{Acknowledgement}

The authors are thankful to professors of Krupanidhi College of Pharmacy for this work. Thanks to IISc for ${ }^{1} \mathrm{H}-\mathrm{NMR} \&$ IR spectral analysis.

\section{References}

1. Bauser M, Delapierre G, Hauswald M, Flessner T, D'Urso D Hermann A, Beyreuther B, De Vry J, Spreyer P, Reissmüller E and Meier H, Bioorg Med Chem Lett., 2004, 14, 1997.

2. Zhang C, Tong H and Yan C, J Comb Chem., 2007, 9, 924.

3. Bendale P M and Sun C M, J Comb Chem., 2002, 4, 359.

4. $\quad$ Minory I, Tatsuki S and Ken-I, Bioog Med Chem Lett., 2004, 14, 5407.

5. Raju B, Noel N and George W Holland, J Comb Chem., 2002, 4,320.

6. Pi-Chi Pan, Chung-Ming Sun, Bioorg Med Chem Lett., 1999, 40, 6443.

7. Cheng-Yi Wu and Chung-Ming Sun, Bioorg Med Chem Lett., 2002, 12, 959.

8. Pi-Chi Pan and Chung-Ming Sun, Tetrahedron Lett., 1999, 39, 9505.

9. Jing-Ying S and Chung-Ming Sun, Bioorg Med Chem Lett., 1999, 9, 519.

10. Ming-Juan L and Chung-Ming S, Tetrahedron Lett, , 2004, 45, 437.

11. Neil M and Smith P E, The Merck Index, $13^{\text {th }}$ Ed, Merck \& Co. Inc., NJ. P-1785, Monograph , 2001, 10074.

12. Kohler P, Int J Parasitol., 2001, 31, 336.

13. Preston P N, Chem Rev., 1974, 74, 279.

14. Thimmegowda N R Nanjunda Swamy S, Ananda Kumar C S, Sunil Kumar Y C, Chandrappa S, George W Yip and Rangappa K S, Bioorg Med Chem Lett., 2008, 18, 432.

15. Vijay K Gore, Vu V Ma, Rami Tamir, Narender R Gavva, James J S Treanor and Mark H Norman, Bioorg and Med Chem Lett., 2007, 17, 5825.

16. Poitout L, Brault V, Sackur C, Bernetière S, Camara J, Plas P and Roubert P, Bioorg and Med Chem Lett., 2007, 15, 4464.

17. Roger J Snow, Asitha Abeywardane, Scot Campbell, John Lord, Mohammed A. Kashem, Hnin Hnin Khine, Josephine King, Jennifer A Kowalski, Steven S Pullen, Teresa Roma, Gregory P Roth, Christopher R Sarko, Noel S Wilson, Michael P Winters, John P Wolak and Charles L, Bioorg and Med Chem Lett., 2007, 17, 3660.

18. Özden Özel Güven, Taner Erdoğan, Hakan Göker and Sulhiye Yıldı, Bioorg and Med Chem Lett., 2007, 2233. 
19. Arienzo R, Sue Cramp, Hazel J Dyke, Peter M Lockey, Dennis Norman, Alan G Roach, Phil Smith, Melanie Wong and Stephen P Wren, Bioorg Med Chem Lett., 2007, 17, 1403.

20. Gerard P Moloney, AG, Graeme R., Martin M M, and Robert C, Eur J Med Chem., 2004, 39, 305.

21. Paul B, John A Christopher, G, Cutler M, Dickson C, Geoffrey W M, James V M, Champa B. P and Lisa M S, Bioorg Med Chem Lett., 2006, 15, 6236.

22. Settimo F.D, Lucacchini A, Marini AM, Martini C, Primofiore G, Senatore G and Taliani S, Eur J Med Chem., 1996, 12, 951.

23. G Romeo, G Ambrosini, S Guccione, A De Blasi and F Russo, Eur J Med Chem., 1993, 28, 499.

24. Pravin M Bendale and Chung Ming Sun, J Comb Chem., 2002, 4, 359. 


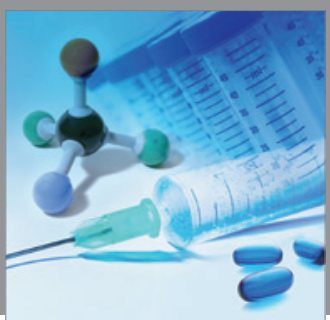

International Journal of

Medicinal Chemistry

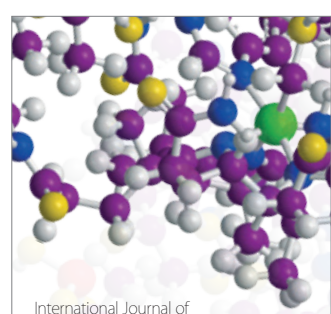

Carbohydrate Chemistry

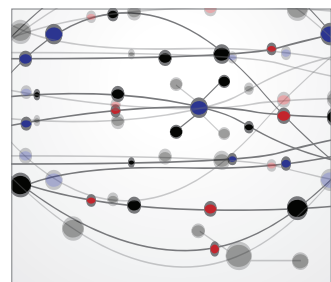

The Scientific World Journal
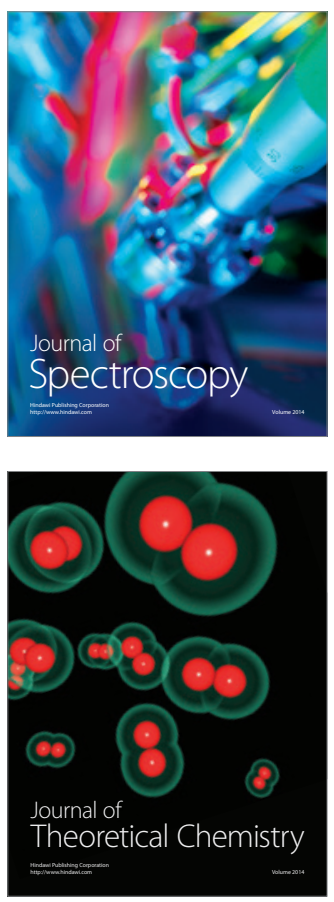
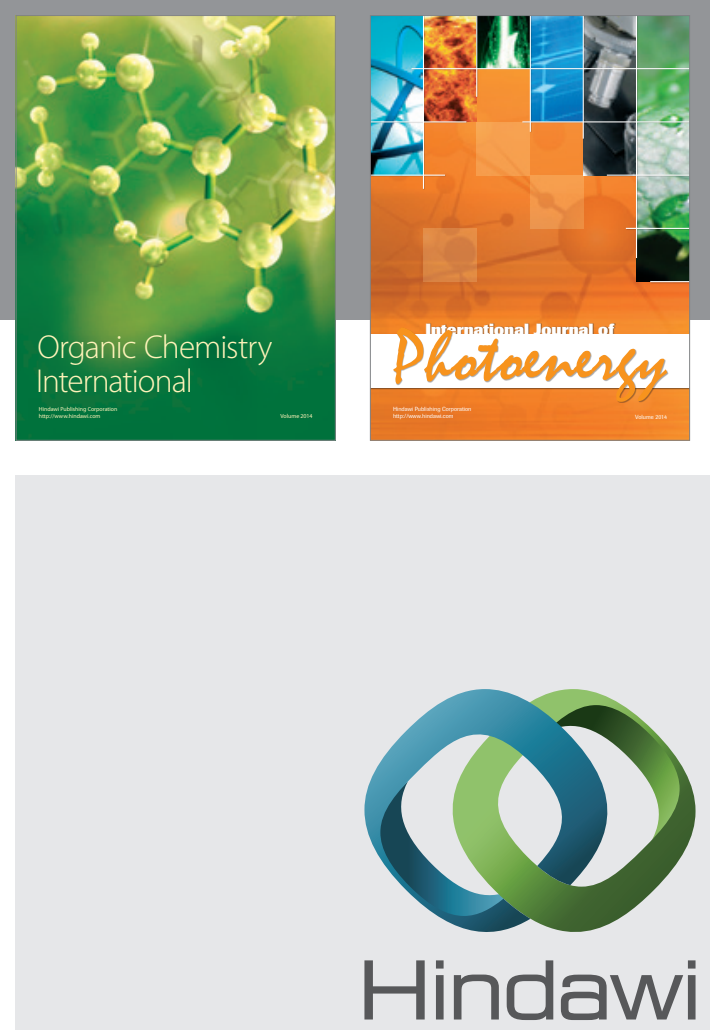

Submit your manuscripts at

http://www.hindawi.com
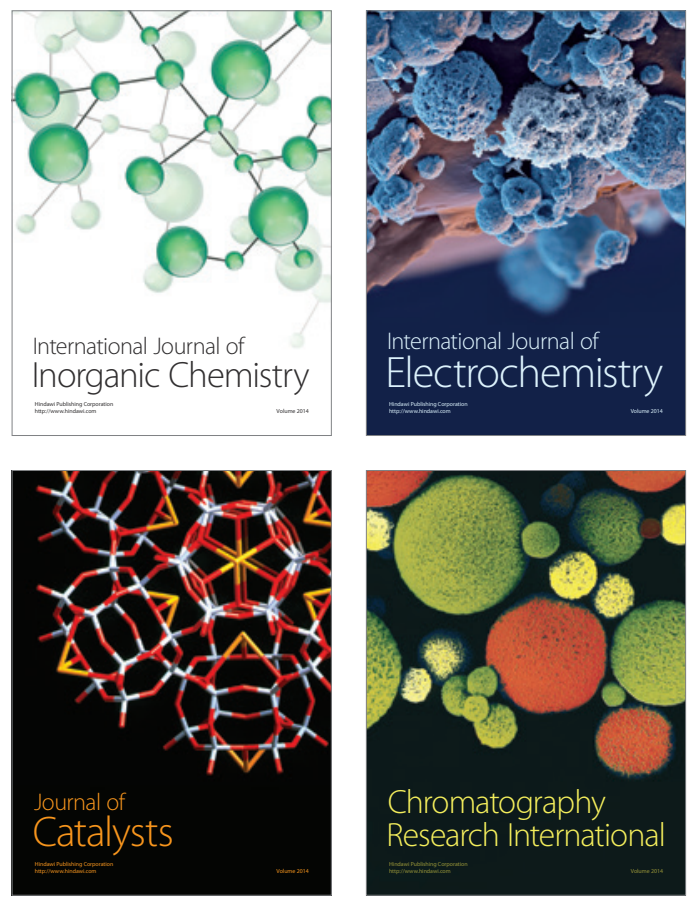
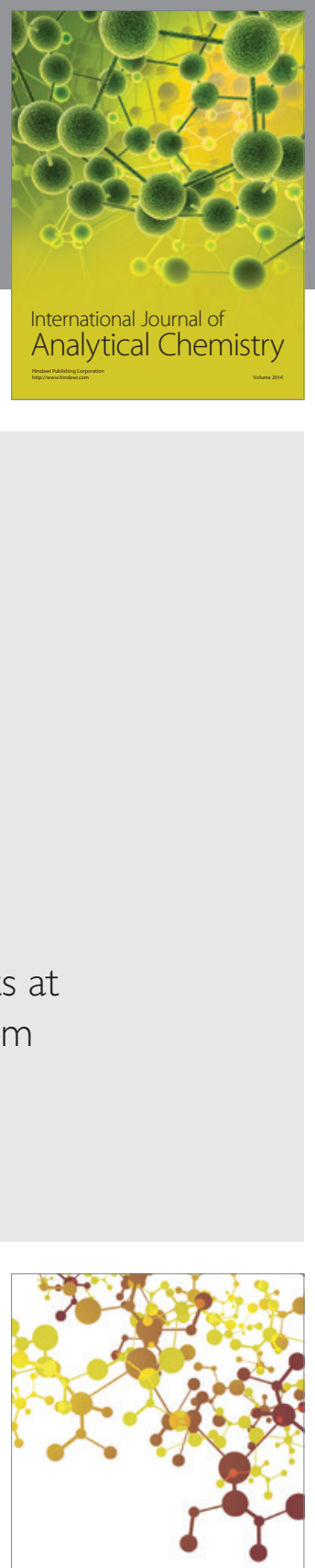

Journal of

Applied Chemistry
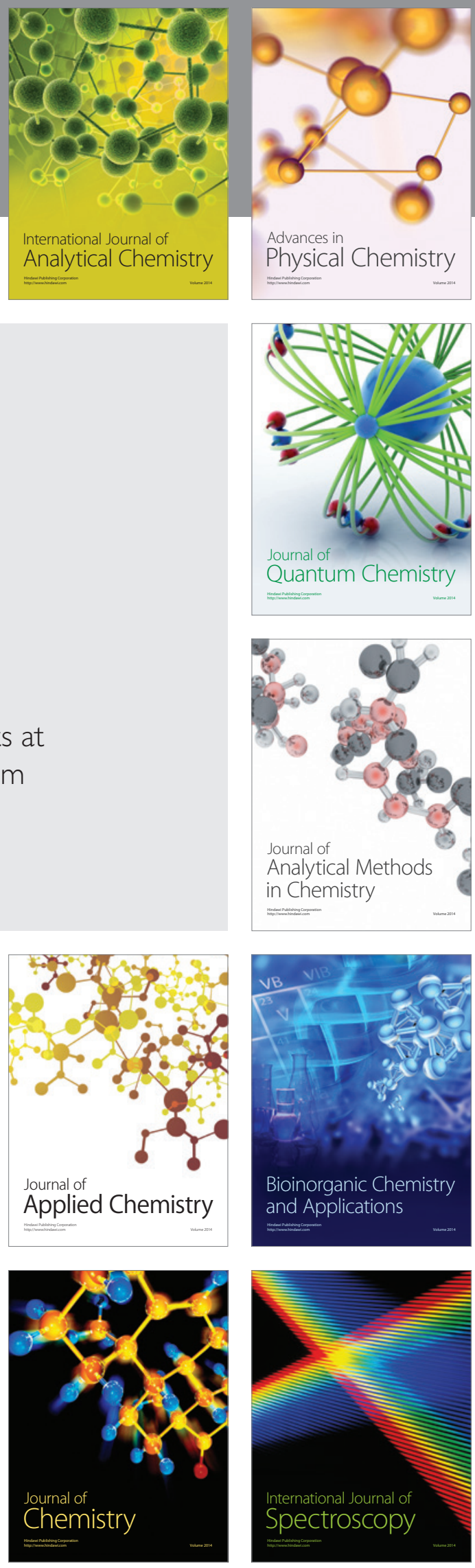